\title{
Introduktion: Politisk psykologi og eksperimenter: Nye krydsdisciplinære veje for Statskundskaben
}

Eksperimenter inden for samfundsfagsforskningen er egentlig ikke noget nyt. Men alligevel har brugen af eksperimenter boomet de senest årtier. Den udvikling skyldes både politologers gryende accept af eksperimenters (alternative) måde at fortolke kausal inferens på, som står i kontrast til de repræsentative large-n observationsstudier, som traditionelt udgør den målestok, hvormed kvaliteten af kvantitativ forskning bliver målt. Men den forøgede brug af eksperimenter skyldes også den forøgede interesse for psykologiske forklaringsfaktorer indenfor politologisk forskning, herunder eksempelvis vælgeradfærd eller demokratiske beslutningsprocesser. Eksperimentet kan nemlig på fornem vis besvare endogene psykologiske problemstillinger, som samfundsvidenskabelig forskning ellers har haft problemer med at undersøge.

Interessen for eksperimenter og politisk psykologi har resulteret i en stærkere forankret tværdisciplinær tilgang inden for økonomi, politologi og psykologi. Dette temanummer fokuserer på denne tværdisciplinære udvikling og indeholder derfor separate bidrag fra eksperimentelle økonomer, politologer og psykologer. I de første tre artikler introduceres den eksperimentelle metode med afsæt i de tematikker, som metoden særligt er blevet brugt til at besvare indenfor økonomi, politologi og psykologi. Temanummerets to sidste bidrag indeholder henholdsvis et eksempel på eksperimentel forskning inden for politisk psykologi og et afsluttende bidrag, som reflekterer over den fremtidige forskning inden for politisk psykologi.

I den første artikel diskuterer Carsten. S. Nielsen (Institut for Psykologi, Københavns Universitet), Alexander C. Sebald og Edward J. D. Webb (Institut for Økonomi, Københavns Universitet) brugen af eksperimenter inden for økonomisk forskning i artiklen: „Understanding Experimental Economics“. Inden for økonomisk forskning er laboratorieeksperimentet det absolut fremherskende. Nielsen, Sebald og Webb fremhæver betydningen af antagelser bag økonomisk teori og fremhæver tre af de vigtigste antagelser, som underligger økonomiske eksperimenter: (1) at deltagerne handler på baggrund af handlingsbaseret payoff genereret i eksperimentet; (2) at deltagerne kun responderer på den eksperimentelle behandling; (3) at deltagerne oplever høj grad af eksperimentel og psykologisk realisme (i.e. de tror på forholdet mellem deres handlinger og deres payoff), og dermed ikke oplever deception. Afslutningsvist diskuterer Nielsen, Sebald og Webb ekstern validitet i økonomiske eksperimenter med udgangspunkt i de tre ovenstående antagelser.

I temanummerets anden artikel „Experimental Methods in Psychology and Cognitive and Affective Neuroscience" forklarer Thomas Habekost (Institut for Psykologi, Københavns Universitet) og Julie Hassing Nielsen (Institut for Statskundskab, Københavns Universitet), hvordan eksperimenter bruges inden for psykologisk forskning. Også psykologien benytter primært laboratorieeksperimenter. Særligt kognitiv psykologi har været under luppen eksperimentelt, og inden for kognitiv neuroscience kombineres ofte adfærdsmål og hjernemål (eksempelvis blodgennemstrømning igennem cortex) for at se korrelationen mellem den psykologiske proces og hjernefunktionen. Artiklen beskriver herudover også de to hyppigst anvendte afhængige variable, præcision og svartid, samt problematikken med at generalisere eksperimentelle resultater fra individ- til samfundsniveau. 
Herudover præsenteres kort den seneste udvikling, hvor studiet af affektiv neuroscience har vundet indpas.

I den tredje artikel „Eksperimenter og Politologisk Forskning: Muligheder og Begransninger" beskriver Julie Hassing Nielsen (Institut for Statskundskab, Københavns Universitet) brugen af eksperimenter politologien, hvor eksperimenter først for nyligt har vundet fast indpas i den politologiske værktøjskasse. Dette skyldes ikke mindst, at politologer traditionelt fokuserer på ekstern validitet, som klassisk opnås i large-n repræsentative observationsstudier. Eksperimentets kausale identifikationsstrategi er derfor en udfordring for den klassiske politologiske måde at tænke inferens på. Artiklen beskriver de tre gængse typer af politologiske eksperimenter - laboratorie-, surveyog felteksperimenter. Hver eksperimenttype beskrives som et trade off mellem muligheden for kontrol af intervenerende variable på den ene side og mundan realisme på den anden. Artiklen afslutter med en kort opridsning af de områder inden for politisk psykologi, hvor eksperimenter med fordel kan bruges.

I temanummerets fjerde artikel „Den Personlige Faktor: Højre- og Venstreorienterede valgere foretrakker forskellige kandidatpersonligheder "illustrerer Lasse Laustsen (Institut for Statskundskab, Aarhus Universitet), hvordan psykologisk teori testet i et eksperimentelt design kan give os ny indsigt i klassiske politologiske problemstillinger, som omhandler vælgeradfærd. I artiklen undersøges via et laboratorieeksperiment, hvorvidt individers præferencer for politiske kandidaters personlighed er forskellige for henholdsvis højre- og venstreorienterede vælgere. Lasse Laustsen demonstrerer igennem sit studie, at højreorienterede vælgere foretrækker dominante kandidatpersonligheder i langt højere grad end venstreorienterede vælgere. Derimod søger venstreorienterede vælgere henimod imødekommende kandidatpersonligheder i langt højere grad end højreorienterede vælgere.

Temanummeret afsluttes af Michael Bang Petersen og Lene Aarøe (Institut for Statskundskab, Aarhus Uni- versitet), som i artiklen „Politisk Psykologi - De Naste Skridt" beskriver, hvordan al politologi essentielt har sin rod i psykologien. Selvom politisk psykologi efterhånden er blevet en etableret gren inden for politologien, står den dog på ingen måde i stilstand. I temanummerets afsluttende artikel fremhæver Michael Bang Petersen og Lene Aarøe den rivende udvikling i politisk psykologi i disse år. I deres artikel behandler de tre overordnede spørgsmål, som hvert især peger os i retning af, hvad vi kan forvente os af studiet af politisk psykologi i fremtiden: (1) Hvad er politisk psykologi, (2) Hvorfor bør man bedrive forskning inden for politisk psykologi og (3) Hvordan bedrives forskning inden for politisk psykologi bedst? De betoner vigtigheden af at tage psykologien alvorligt i politologisk forskning - og understreger, at politologer må indarbejde de psykologiske indre dynamikker i deres aktørmodeller, ligesom de særlige kontekstuelle og metodiske forhold, som gør sig gældende inden for politologisk forskning altid skal tages i betragtning.

Uden for tema bringes to artikler. Den første „Er friheden taget ud affriskolen?" er forfattet af Tore Vincents Olsen (Institut for Statskundskab, Aarhus Universitet). Her undersøger han, hvorvidt de seneste 15 års lovbestemmelser om friskolernes ideologiske og pædagogiske frihed har betydet en indskrænkning af friskolernes selvbestemmelse. Den anden artikel „Resultatmåling $i$ nyt terran. En undersøgelse af måleusikkerheder på det specialiserede ungeområde" af Jeppe Agger Nielsen (Institut for Statskundskab, Aalborg Universitet) og Britt Søvsø Mikkelsen (Aarhus Kommune) undersøger måleusikkerheder på det specialiserede ungeområde gennem et casestudie af Aarhus Kommunes anvendelse af resultatdokumentation. Temanummeret rundes af med en boganmeldelse af Carsten Greves bog "Reformanalyse - Hvordan den offentlige sektor grundlaggende er blevet forandret i 00'erne".

Julie Hassing Nielsen, Temaredaktør 